\title{
Hormonal regulation of the partition of energy between milk and body tissue in adult cattle
}

\section{By J. A. Bines and I. C. HART, National Institute for Research in Dairying, Shinfield, Reading, Berks. $R G_{2} g A T$}

It is well recognized that some breeds of cattle use dietary energy preferentially for laying down body tissue and that lactating females of these breeds give only modest yields of milk. In contrast, cows of modern dairy breeds give average milk yields in excess of $5000 \mathrm{~kg}$ per year and at peak of lactation often produce more than $30 \mathrm{~kg}$ milk per day. This fact, in conjunction with an appetite which is generally low during early lactation (Bines, 1978), necessitates all the energy of the ration which is available for productive purposes being used for milk synthesis and even so, an energy deficit often remains, to be made good by mobilization of body tissue (Table I). Similar trends, but on a smaller scale, are observed between

Table I. Variation in food utilization between cows of a dairy type (Friesian) and a beef type (Hereford-cross) given equal rations for the first $84 d$ of lactation

$\begin{array}{lrr} & \text { Beef } & \text { Dairy } \\ \text { Initial live weight }(\mathrm{kg}) & 436 & 450 \\ \text { Total milk yield }(\mathrm{kg}) & 518 & 1673 \\ \text { Live weight change }(\mathrm{kg}) & +44 & -45\end{array}$

individuals of the same breed so that the 'good' dairy cow is one which channels all available food energy towards milk and makes good any energy deficit for milk production by mobilizing body tissue; while the converse is a 'poor' dairy cow (Table 2) (Broster et al. 1969). It is clear that these differences in energy partition both between and within breeds are genetic in origin and that they are probably mediated via differences in the balance of hormones responsible for the control of energy metabolism. If the circulating concentrations of these hormones are an important factor in this process it is not clear what quantitative differences in hormone levels are responsible for these differences in performance, how they are influenced or whether they can be manipulated towards any desired end. It is the

Table 2. Variation in food utilization in two dairy heifers given equal rations for the first $67 \mathrm{~d}$ of lactation

$\begin{array}{lcr} & \text { Cow A ('Poor') } & \text { Cow B ('Good') } \\ \text { Initial live weight (kg) } & 517 & \mathbf{5 2 0} \\ \text { Total milk yield (kg) } & 837 & 1325 \\ \text { Live weight change }(\mathrm{kg}) & +39 & -5^{2}\end{array}$


purpose of this review to evaluate the evidence which is available on these topics in ruminants.

The capacity of the cow to produce milk is a function of the development of the mammary gland during pregnancy and the ability of the cow to provide the necessary substrates for milk synthesis once lactation is established. The former is beyond the scope of the present paper and will not be considered further here. $A$ wide range of hormones is known to influence energy metabolism and as well as the individual endocrine effects, there are hormone/hormone and hormone/ receptor interactions to be considered.

\section{Role of individual hormones}

Growth Hormone. (GH) Highly purified bovine GH has been shown to have an intrinsic lipolytic activity (Lee et al. 1974; see also discussion Hart et al. 1978a). Thus, its role in mobilizing body fat as a source of energy and of diverting food energy away from tissue synthesis may be considerable. Ingalls et al. (1973) have demonstrated raised levels of $\mathrm{GH}$ in the serum of heifers at parturition, and Convey (1974) considers that this may be associated with changes in body metabolism at this time to meet the increased demand for energy and protein at the onset of lactation. Administration of exogenous GH to heifers around the time of parturition increased milk production and the effect persisted throughout lactation (Shaw, 1955). A similar effect on milk yield at the time of GH administration was also observed by Brumby \& Hancock (1955), but in this case the response did not persist.

At the time of peak lactation, plasma GH concentration was high in cows producing high milk yields and declined as lactation advanced (Hart et al. 1978a) but in lower yielding cows of beef type, $\mathrm{GH}$ levels were relatively low throughout lactation. Changes in $\mathrm{GH}$ concentration were positively correlated with changes in milk yield (Hart et al. 1978b) and were negatively related to body weight. Associated with the high levels of $\mathrm{GH}$ at peak lactation, were high levels of nonesterified fatty acids (NEFA) in plasma, changes in levels of these two substances being positively correlated (Hart et al. 1978b). Johnson et al. (1976) also demonstrated higher circulating levels of $\mathrm{GH}$ in high-yielding Holstein cows than in lower yielders of the same breed.

The response of GH to short-term changes in the nutritional status of the cow is not clear. McAtee \& Trenkle (1971) found that blood levels of GH in cattle were not affected by feeding or fasting, or by the intravenous infusion of volatile fatty acids. Our own work has also failed to reveal any diurnal pattern of plasma GH concentration in relation to feeding (Bines \& Hart, unpublished results). In contrast, in sheep fed frequently, Bassett et al. (1971) found that mean plasma GH concentrations were negatively correlated with digestible organic matter intake and with plasma insulin concentration. Bassett (1975) has suggested that a reduction in the frequency of the episodic releases of $\mathrm{GH}$ after feeding, leads to a reduction in the mean concentration of the hormone after feeding.

Recently, we have examined the effects of daily subcutaneous injections of GH 
over a $7 \mathrm{~d}$ period. Using beef- and dairy-type cows in mid-lactation, when endogenous GH would not be expected to be very high, and avoiding plasma GH levels excessively above physiologically normal values, we have demonstrated an increase in milk yield in the last $3 \mathrm{~d}$ of the injection period $15 \%$ greater than the pre-injection yield; the increase was proportionately similar in both types of cow. The daily yields of milk protein and lactose were also raised significantly but fat yields were variable. After the injections ceased, yields of milk and constituents returned to the previous control levels. The cows were not allowed to consume extra food during the infusion period, therefore the increased milk yield must have resulted from altered partition of nutrients between milk and body tissue. During the period of GH infusion, the level of glucose was raised in the plasma of the beef cows but not in the dairy cows. This suggests that GH may have increased the availability of glucose to the mammary gland, but the small absolute increase in milk yield of the beef cows was not able to utilize this, whereas the larger absolute increase in yield of the dairy cows did use the extra glucose and therefore no increase in the circulating level was evident. There were no other results which allowed us to draw a conclusion about the primary site of action of the hormone. A similar effect of growth hormone in raising the efficiency of milk synthesis was observed by Hutton (1957) and Machlin (1973). Nitrogen balance was also altered, the increased milk protein yield being reflected in a reduced excretion of $\mathrm{N}$ in the urine. (Hart, Bines, Morant, unpublished data). Although fragments of HGH have been prepared which retain lipolytic activity (Yudaev et al. 1976), attempts to prepare a fragment of bovine $\mathrm{GH}$ capable of increasing milk yield have so far been unsuccessful (Hart \& Bines, unpublished data).

If, as seems likely, GH stimulates an increase in the amount of energy used for milk synthesis, without an increase in basal metabolic rate as is the case with exogenous thyroxine (Blaxter, 1952), consideration must be given to the possibility of raising $\mathrm{GH}$ level in the blood of cows as a means of increasing the efficiency of food utilization for milk synthesis. There are three ways of increasing blood GH level: environmental, pharmacological and nutritional; some of these have been examined at Shinfield.

With regard to environmental influences; studies in male goats indicated no seasonal changes in GH (Hart \& Buttle, 1975). Similarly measurement of circulating $\mathrm{GH}$ in goats at frequent intervals throughout $24 \mathrm{~h}$ periods has failed to demonstrate a diurnal rhythm or a relationship with stages of sleep and ambient temperature (Hart et al. 1975; Tindal et al. 1978). Although many pharmacological substances are known to stimulate GH secretion they are all either non-specific or have undesirable side effects. Release of GH from the pituitary gland is inhibited by somatostatin, thus if somatostatin itself can be inhibited, an increased release of GH may result. Levels of somatostatin have been depressed in rats by use of an antibody (Arimura et al. 1975), but attempts to achieve the same effect in cows have not been successful so far (Hart \& Bines, unpublished data). Davis et al. (1970) have shown that sheep responded in a similar way to administration of growth hormone and of diethylstilboestrol, both 
causing a considerable increase in $\mathrm{N}$ retention. Annison (1976) has suggested that this may have been due to a stimulation of $\mathrm{GH}$ release by the synthetic oestrogen.

Nutritionally, infusions of casein into the abomasum of lactating cows have given rise to marked increases in the yield, fat and protein contents of milk ( $\emptyset$ rskov et al. 1977). A similar effect in lactating goats (Ranawa \& Kellaway, 1977) was thought possibly to be mediated via enhanced GH secretion. Accordingly, we have attempted to raise plasma $\mathrm{GH}$ in lactating goats and beef cows by means of abomasal infusions of casein. Preliminary results (Oldham et al. 1978) indicate that we were successful and an attempt is now under way to achieve a similar effect by feeding protected protein to lactating cows.

Insulin. The role of insulin in the control of metabolism is essentially anabolic in nature. It stimulates the uptake and utilization of glucose by many peripheral tissues, inhibits gluconeogenesis and glucose release from the liver, stimulates the uptake and incorporation of amino acids into protein, inhibits proteolysis, stimulates lipogenesis and inhibits lipolysis (Bassett, 1975). The utilization of acetate by peripheral tissues is strongly stimulated by insulin (Yang \& Baldwin, 1973). Thus it would be expected to be associated with diversion of food energy from milk synthesis towards deposition of body tissue. It has been demonstrated that plasma insulin level throughout lactation is at least twice as great in lowyielding cows as in those giving acceptable yields (Hart et al. 1978a) and only when lactation has ended do the levels become comparable in the two groups of animals. Changes in plasma insulin were significantly and positively correlated with body-weight change and changes in the ratio $\mathrm{GH} /$ insulin, thought by some to be involved in fat mobilization (Rabinowitz et al. 1966), were positively associated with changes in milk yield (Hart et al. $1978 b$ ). Injection of insulin in lactating cows depressed milk yield (Kronfeld et al. 1963).

In contrast to $\mathrm{GH}$, the level of insulin is very responsive to short-term changes in the energy status of the cow. The level falls in the starved animal (Trenkle, 1978) and is low before feeding (Bines \& Hart, unpublished results), rising markedly after a meal, the change in concentration sometimes being as large as six-fold (Bines \& Hart, unpublished results).

Consideration must also be given to the role of insulin in control of gluconeogenesis in the liver; in this context it is necessary to examine also the simultaneous role of glucagon. Unger (1971) has suggested that the molar ratio of the two hormones may be of more importance than their absolute concentrations and Bassett (1975) has considered this possibility for the control of ruminant hepatic metabolism. Thus, at times of energy deficit, I:G is low, hepatic output of glucose is maximal and peripheral utilization of glucose is minimized. At the other extreme, in animals given a diet high in available carbohydrate, $I: G$ is high, hepatic gluconeogenesis is depressed and peripheral utilization is maximal.

There is insufficient evidence available at the present time, to draw firm conclusions about the factors affecting insulin level in the blood of the cow and therefore means of influencing the level cannot be devised. In sheep, the release of insulin after a meal is biphasic (Bassett, 1975); the initial peak is thought to be 
stimulated either neurally or by the action of gastrointestinal hormones on the pancreas (Trenkle, 1978) while the size of the second larger peak, occurring some ${ }^{2-4} \mathrm{~h}$ after a meal, appears to be related to the amount of dietary energy consumed (Bassett, 1975). Numerous attempts have been made to relate this second peak to absorption of volatile fatty acids (VFA) from the rumen (see Trenkle, 1978), but firm conclusions cannot be drawn. Undoubtedly, in vitro, the pancreas releases insulin in response to several VFAs both individually and in mixtures, but the concentrations used are probably encountered rarely, if at all in vivo. Bassett (1975) has suggested that the flow of protein into the intestines may be a determinant of insulin level, possibly via the gastrointestinal hormones. Insulin release is also not necessarily related to a rise in blood glucose level, indeed, the latter may actually fall when insulin levels are rising (Bassett, 1975; Bines, unpublished results). It is known that when diets containing a high proportion of starchy concentrates are given to ruminants, the level of insulin in blood is raised (Trenkle, 1970). However, reducing the amount of concentrate in the ration would be unlikely to increase the total energy supply to the mammary gland since the increased mobilization of energy from body tissues is likely to be offset by a reduction in the intake of dietary energy (Bines, 1978).

Glucagon. Measurement of this hormone in blood is complicated by problems of specificity and available commercial kits are expensive, therefore results are severely limited and we are not aware of any derived from lactating cows. From the known functions of glucagon, it is likely that it would play a major role in controlling energy metabolism in the cow. It is known to decline during fasting and increase after feeding in sheep (Bassett, 1972) and it is probably the main hormone controlling hepatic metabolism (Bassett, 1975). Its release can be stimulated by unphysiologically large intravenous injections of propionate and butyrate (Bassett, 1972). A role for glucagon in controlling lipolysis in ruminant adipose tissue has been proposed (Bauman \& Davis, 1975) but the evidence was limited. The release of glucagon in response to feeding closely parallels the release of insulin in sheep (Bassett, 1972).

Prolactin. A role for prolactin in promoting lipogenesis in early lactation in the cow was proposed by Swan (1976). There is no further evidence in favour of this theory however and our own work (Hart et al. 1978a) showed no significant differences in prolactin concentration in early lactation between high- and lowyielding cows.

Thyroxine. During lactation, plasma thyroxine levels were not significantly different between high- and low-yielding cows receiving the same ration (Hart et al. 1978a). Levels in both types of animal were lower at peak lactation than after lactation had ended however (Hart et al. 1978b), there being a significant negative correlation between total milk yield and plasma thyroxine level (Hart et al. $1978 b$ ) in the high-yielders. Changes in plasma $T_{4}$ were negatively correlated with changes in milk yield in both groups of cows (Hart et al. 1978b). There was no diurnal variation in plasma thyroxine level in relation to feeding (Bines, Hart, Morant, unpublished results) although removal rate of the hormone from plasma is 
known to be lowered when food intake is limited (Lundgren \& Johnson, 1964).

Hormone Receptors. Since the adoption of radioimmunoassay procedures for the measurement of circulating hormones, it has become evident that changes in the concentrations of hormones in blood are not necessarily accompanied by appropriate changes at the target organ (Kahn, 1976). Additional mechanisms are present which influence the hormone sensitivity of the target tissue. The concept of the hormone receptor has evolved throughout the last decade and maintains that the primary step in the action of peptide hormones involves binding to a stereospecific receptor site on the target cell plasma membrane (Catt \& Dufau, 1977). Gluconeogenic processes in the liver are a crucial factor in the provision of milk precursors at peak lactation in ruminants, and it is well known that glucagon and possibly insulin may be involved in the regulation of these processes (Unger, 1977). However, preliminary work at Shinfield (Gill \& Hart, unpublished data) has established that, when compared to non-lactating sheep, there is a significant fall in the quantity of glucagon bound to hepatocytes isolated from sheep at peak lactation (20 d) and probably in energy deficit. This is followed by a substantial increase in specific binding at $50 \mathrm{~d}$ of lactation, significantly greater than that in either non-lactating animals or animals at peak lactation. The binding of insulin to the hepatocytes increased as lactation progressed. The implications of these results are being investigated.

Mammary gland development is essentially complete at the time of parturition. Therefore the maximum synthetic potential of the gland is already set at the onset of lactation, and the realization of this potential depends on the adequacy of the supply of nutrients to the gland. Dietary energy alone is not likely to be adequate to meet the total requirements of the gland due to appetite limits in early lactation, therefore mobilization of energy from body tissues is necessary to make good the deficit. Maximum mobilization is favoured by high levels of growth hormone and low levels of insulin in the blood, and the level of glucagon is probably very important also. The prospects for influencing these levels nutritionally or pharmacologically appear promising.

\section{REFERENCES}

Annison, E. F. (1976). In Principles of Cattle Production, p. 190. [H. Swan and W. H. Broster, editors]. London: Butterworths.

Arimura, A., Sato, H., Coy, D. H. \& Schally, A. V. (1975). Proc. Soc. exp. Biol. Med. 148, 784.

Bassett, J. M. (1972). Aust. F. biol. Sci. 25, 1277.

Bassett, J. M. (1975). In Digestion and Metabolism in the Ruminant, p. 383. [I. W. McDonald and A. C. I. Warner, editors]. Armidale: University of New England Publishing Unit.

Bassett, J. M., Weston, R. H. \& Hogan, J. P. (1971). Aust. F. biol. Sci. 24, 321 .

Bauman, D. E. \& Davis, C. L. (I975). In Digestion and Metabolism in the Ruminant, p. 496. [I. W. McDonald and A. C. I. Warner, editors]. Armidale: University of New England Publishing Unit.

Bines, J. A. (1978). In Report of Study Group on Feeding Strategy for the High-Yielding Cow. E.A.A.P. (In the Press).

Blaxter, K. L. (1952). Vitams Horm. 10, 217.

Broster, W. H., Broster, V. J. \& Smith, T. (1969). Y. agric. Sci., Camb. 72, 229. 
Brumby, P. J. \& Hancock, J. (1955). N.Z. Fl Sci. Technol. A36, 417.

Catt, K. J. \& Dufau, M. L. (1977). A. Rer. Physiol. 39, 529.

Convey, E. M. (1974). J. Dairy Sci. 57, 905.

Davis, S. L., Garrigus, U. S. \& Hinds, F. C. (1970). F. Anim. Sci. 30, 236.

Hart, I. C., Bines, J. A., Morant, S. V. \& Ridley, J. L. (1978a). F. Endocr. 77, 333.

Hart, I. C., Bines, J. A. \& Morant, S. V. (1978b). F. Dairy Sci. (In the Press).

Hart, I. C. \& Buttle, H. L. (1975). F. Endocr. 67, 137.

Hart, I. C., Flux, D. S., Andrews, P. \& McNeilly, A. S. (1975). Horm. Metabolic Res. 7, 35.

Hutton, J. B. (1957). F. Endocr. 16, I15.

Ingalls, W. G., Convey, E. M. \& Hafs, H. D. (1973). Proc. Soc. exp. Biol. Med. 143, 16r.

Johnson, M. D., De Dios, O. \& Lippincott, A. C. (1976). In IAEA/FAO Symp. Nuclear Techniques in Animal Production and Health, p. 555

Kahn, C. R. (1976). In Cell membrane receptors for viruses, antigens and antibodies, polypeptide hormones and small molecules, p. 33. [R. F. Beers and E. G. Bassett, editors]. New York: Raven Press.

Kronfeld, D. S., Mayer, G. P., Robertson, J. M. \& Raggi, F. (1963). J. Dairy Sci. 46, 559.

Lee, V., Ramachandran, J. \& Li, C. H. (1974). Archs Biochem. Biophys. 161, 222.

Lundgren, R. G. \& Johnson, H. D. (1964). Y. Anim. Sci. 23, 28.

Machlin, L. J. (1973). F. Dairy Sci. 56, 575.

McAtee, J. W. \& Trenkle, A. (197 I). J. Anim. Sci. 33, 438.

Oldham, J. D., Hart, I. C. \& Bines, J. A. (1978). Proc. Nutr. Soc. 37, 9A.

Orskov, E. R., Grubb, D. A. \& Kay, R. N. B. (1977). Br. F. Nutr. 38, 397.

Rabinowitz, D., Merimee, T. J. \& Burgess, J. A. (1966). Diabetes $15,905$.

Ranawa, S. S. E. \& Kellaway, R. C. (1977). Br. F. Nutr. 37, 395.

Shaw, J. C. (1955). In The hypophyseal growth hormone, nature and actions. [R. W. Smith, O. H. Gaebler and C. N. H. Long, editors]. New York: McGraw-Hill.

Swan, H. (1976). In Principles of Cattle Production, p. 85. [H. Swan and W. H. Broster, editors]. London: Butterworths.

Tindal, J. S., Knaggs, G. S., Hart, I. C. \& Blake, L. A. (1978). F. Endocr. 76, 333.

Trenkle, A. (1970). F. Nutr. 100, 1323 .

Trenkle, A. (1978). F. Dairy Sci. 61, 28 r.

Unger, R. H. (1971). Diabetes 20, 834 .

Unger, R. H. (1977). In The year in metabolism in 1975-1976, p. 73. [N. Freinkel, editor]. New York and London: Plenum Medical Book Company.

Yang, Y. T. \& Baldwin, R. L. (1973). F. Dairy Sci. 56, 350.

Yudaev, N. A., Pankov, Yu. A., Keda, Yu. M., Shvachkin, Yu. P., Ryabtsev, M. N. \& Chukashev, S. G. (1976). Biochemistry N.Y. 41, 691. 